This is an electronic reprint of the original article. This reprint may differ from the original in pagination and typographic detail.

Author(s): Saarijärvi, Hannu; Karjaluoto, Heikki; Kuusela, Hannu

Title: $\quad$ Extending customer relationship management. From empowering firms to empowering customers

Year: $\quad 2013$

Version:

Please cite the original version:

Saarijärvi, H., Karjaluoto, H., \& Kuusela, H. (2013). Extending customer relationship management. From empowering firms to empowering customers. Journal of Systems \& Information Technology, 15(2), 140-158.

https://doi.org/10.1108/13287261311328877

All material supplied via JYX is protected by copyright and other intellectual property rights, and duplication or sale of all or part of any of the repository collections is not permitted, except that material may be duplicated by you for your research use or educational purposes in electronic or print form. You must obtain permission for any other use. Electronic or print copies may not be offered, whether for sale or otherwise to anyone who is not an authorised user. 
Accepted for publication in the Journal of Systems \& Information Technology

\title{
EXTENDING CUSTOMER RELATIONSHIP MANAGEMENT: FROM EMPOWERING FIRMS TO EMPOWERING CUSTOMERS
}

\author{
Hannu Saarijärvi, Program Manager \\ School of Management \\ Research and Education Centre Synergos \\ University of Tampere \\ FIN-33014 University of Tampere, Finland \\ Tel. +358 405351369 \\ Fax. +358335516020 \\ E-mail: hannu.saarijarvi@uta.fi
}

Hannu Saarijärvi is a program manager in the Research and Education Centre Synergos at the

University of Tampere, Finland. His research interests lie in value co-creation, service marketing and customer relationship management. He has published in Industrial Marketing Management and Journal of Strategic Marketing.

\author{
Heikki Karjaluoto, Professor \\ Department of Marketing \\ School of Business and Economics \\ University of Jyväskylä \\ PO Box 35 \\ FIN-40014 University of Jyväskylä, Finland \\ Tel. +358 405767814 \\ Fax. +358 142601021 \\ E-mail: heikki.karjaluoto@jyu.fi
}

Heikki Karjaluoto is a professor in marketing at the University of Jyväskylä, Finland. His research interests include electronic business in general and mobile business and commerce in particular. Previous publications have appeared in the Electronic Markets, European Journal of Marketing, Internet Research,

International Journal of Electronic Business, International Journal of Mobile Communications,

International Journal of Mobile Marketing, Journal of Systems \& information Technology, Online Information Review, Telecommunications Policy, among others.

\author{
Hannu Kuusela, Professor \\ School of Management \\ University of Tampere \\ FIN-33014 University of Tampere, Finland \\ Tel. +358500624837 \\ Fax. +358335516020 \\ E-mail: hannu.kuusela@uta.fi
}

Hannu Kuusela is a professor of marketing at the University of Tampere, Finland. His research interests lie in consumer behaviour and marketing strategy. In addition to textbooks and chapters for books (focusing on the marketing of services, customer value, and risk management), he has published articles in the American Journal of Psychology, European Journal of Marketing, Industrial Marketing Management, Journal of Professional Services Marketing, International Journal of Retail \& Distribution Management, and the Journal of Financial Services Marketing. 
Accepted for publication in the Journal of Systems \& Information Technology

\title{
EXTENDING CUSTOMER RELATIONSHIP MANAGEMENT: FROM EMPOWERING FIRMS TO EMPOWERING CUSTOMERS
}

\begin{abstract}
Purpose - The focus of customer relationship management (CRM) literature has been predominantly on the firm perspective and on IT, not on customer or service orientation and value co-creation. This paper explores and analyses contemporary CRM frameworks and suggests future research directions. To achieve this, a thorough literature review on CRM is conducted focusing on recent advances within CRM. This provides a good basis for critically analysing the current status of both CRM theory and practice.
\end{abstract}

Design/methodology/approach - We review CRM literature published 2003-2011. Based on the literature review, we introduce a conceptual framework of the changing role of customer data in the CRM framework.

Findings - Literature has not adequately addressed the role of the emerging service orientation, value co-creation and the opportunities provided by new technology and communication channels. Drawing on a thorough CRM literature review, we argue that a fundamental change in CRM thinking is needed to shift the focus of CRM from empowering firms to empowering customers.

Research limitations/implications - The paper is conceptual in nature and presents only a few empirical examples of the changing role of customer data within the CRM framework. The 
Accepted for publication in the Journal of Systems \& Information Technology

paper calls for more research on the emerging service orientation, value co-creation and the impact of new media on the contemporary CRM framework.

Practical implications - Customer data remain, and will remain, a critically important input resource informing a firm's processes. However, using customer data for the benefit of the customer too, to serve customers better, is clearly an emerging phenomenon. Refining and giving customer data back to customers may represent a future mechanism through which companies deepen and develop their customer relationship management to a whole new level.

Originality/value - The study is among the first attempting to critically evaluate the contemporary CRM framework from the perspective of empowering customers.

Keywords - customer relationship management, customer data, customer centricity, servicedominant logic, new media

Paper type - Conceptual paper.

\section{INTRODUCTION}

Customer Relationship Management (CRM) is generally defined as the management of mutually beneficial relationships (LaPlaca, 2004), in which customer data often has a major role (see e.g. Verhoef and Langerak, 2002). The diversity of the theoretical, practical, and managerial discussion around CRM is well characterized within its current domain that often applies two classifications: the strategic and the operational perspective (Richards, et al., 2006). From the 
Accepted for publication in the Journal of Systems \& Information Technology

strategic perspective, the core idea of CRM is to develop strategies to attract (the right) customers and maximize their lifetime value by fostering their loyalty. CRM is all about acquiring, cultivating, managing, and retaining customers, which is why it underlines the importance of relationship strategy and the process used to identify customers, create customer knowledge, build customer relationships, and shape customer perceptions of the firm and its products and solutions. Furthermore, strategic CRM determines how a firm relates to its customers via channels, messages, products, and services (Richards et al., 2006).

The operational perspective on CRM, in turn, deals with automating customer-facing processes such as interactions and general front-office processes including sales, marketing and customer service. According to Peppers and Rogers (2011, p. 9), operational CRM 'focuses on the software installations and the changes in process affecting the day-to-day operations of a firm - operations that will produce and deliverer different treatments to different customers'. This definition also reveals the very nature of the customer-focused way of doing business: treat different customers differently. Both practitioners and scholars identify analytical CRM, referring to plans needed to build customer value by managing customer databases to perform data analysis like data mining, as a third angle of CRM (e.g. Peppers and Rogers, 2011, p. 9).

Conceptual complexity around CRM is further deepened, for example, by Parvatiyar and Sheth (2001) who underline the importance of CRM in integrating different company functions such as marketing, sales, customer service and supply chain functions to enhance efficiency in delivering value. The process-oriented definitions encourage companies to gather customer data, identify the most valuable customers over time, and increase customer loyalty by providing customized products and services (Rigby et al., 2002). In contrast, the managerial meaning of the term CRM refers to the collection of customer data and other activities related to the 
Accepted for publication in the Journal of Systems \& Information Technology

management of the customer-firm interface (Boulding et al., 2005), and so resembles the definition of operational CRM.

Despite the increasing managerial interest in CRM, as well as the scholarly interest in both its operational and strategic perspectives, the CRM activity being undertaken by firms may be inadequate. This is due to many reasons. Companies are increasingly shifting attention from selling goods to supporting customers' value-creating processes, which is related to the current marketing thinking emphasizing intangibility, exchange processes and relationships (e.g. Vargo and Lusch, 2004; 2008). As part of their quest to provide a better service, firms are establishing service applications where customer data is used for the benefit of the customer instead of the overarching focus on firm's value creation, as is largely emphasized within the contemporary CRM framework. Moreover, perceptions of the conventional roles of customers and firms are constantly being adjusted and reconfigured. Both customers and firms implement new ways to engage in each other's value-creating processes, often referred to as value co-creation. Certainly, the changes in the operational CRM and communications landscape, such as the evolution of the customer from a passive receiver of marketing communications to an active partner and discussant (Hennig-Thurau et al., 2010), opens up new opportunities for value creation for the firm and the customer, as well as offering a new source of customer data.

To avoid acting on a yesterday's logic, CRM needs to evolve and reconfigure its very nature in order to better serve future business purposes. To address this challenge, the purpose of this paper is to explore and analyse the contemporary CRM framework and identify future research directions. To achieve this, a thorough literature review is conducted focusing on recent advances within CRM. This provides a good basis for critically analysing the current status of both CRM theory and practice as well as provide implications for future research. 
Accepted for publication in the Journal of Systems \& Information Technology

The remainder of this article is structured as follows. First, the research methodology is presented including a detailed description of the literature review process. Second, the results of the literature review are discussed in two phases: i.e. empowering firms and empowering customers, after which implications for the CRM framework are provided before the paper concludes with a discussion section.

\section{RESEARCH METHODOLOGY}

The reasons for conducting the literature review were twofold. First, it provided a systematic way to evaluate the characteristics of the recent developments within the CRM framework. Second, it provided well-grounded insights into emerging CRM trends and shifts in thinking. Consequently, the literature review offered a conceptual and empirical basis for addressing the research purpose of exploring and analysing the contemporary CRM framework and identifying future research directions.

Given the diverse nature of the CRM framework, the studies that have contributed to its domain radiate from a number of journals from various disciplines. Consequently, online journal databases (ABI/Inform, EBSCO Business Source Premier, Emerald Full-Text, and Web of Science), journal special issues and other literature reviews were used to inform the current literature review. In order to assess the contemporary CRM domain the search was limited to articles published after the review period (1992-2002) used in a study by Ngai (2005). In the first phase, a search was conducted using the term 'customer relationship management'. This yielded over 2,500 scientific articles prompting the authors to limit the search to articles that contained the search term in the article title, keywords, or abstract. An additional manual search in international, scientific, peer-reviewed, high-quality marketing journals, for example The 
Accepted for publication in the Journal of Systems \& Information Technology

Journal of Marketing, Journal of the Academy of Marketing Science, Journal of Business Research, was conducted. In a manner similar to Ngai (2005), the articles' overall contribution to the current CRM literature and the journal's relevance in terms of business, marketing, management, IT, and IS research were evaluated. Articles unrelated to CRM were excluded. The process resulted in 154 papers after which emphasis was placed on identifying the most relevant articles in terms of the paper's objective, theoretical background, methodology, results and overall contribution. The intention was to ensure that the literature in the CRM field that appeared after 2002 was identified with a focus on the studies most aligned with the research objectives. Thus, papers that managed to clearly contribute to the CRM domain theoretically, practically or methodologically were included to the final selection of papers. Papers that didn't directly address these issues and characteristics or were based on mixture of different theoretical approaches were excluded. These selection criteria further decreased the number of appropriate papers to 50. Table 1 lists the 50 papers used for the final review and classifies the papers by year of publication (in descending order), author(s), paper title, journal and an indication of whether the paper is conceptual or empirical.

\section{"Take in Table 1 about here"}

Given the research purpose of exploring and analysing contemporary CRM frameworks as well as identifying future research directions, the more detailed analysis of the selected papers were driven by an emphasis on CRM related themes and characteristics addressed by the papers. The researchers avoided taking a too narrow or limited approach to CRM, but concentrated on 
Accepted for publication in the Journal of Systems \& Information Technology

identifying emerging themes and broader perspectives addressed by the papers aiming at building a condensed analysis of the CRM framework.

\section{RESULTS}

The results of the literature review illuminate the pluralistic nature of CRM research. The discussion around CRM is multifaceted conceptually, empirically and practically. Since 2003, the domain has become even more fragmented and empirically inconsistent, which has impeded the development of a synthesized and common theoretical basis and as a result, can affect its ability to adapt to changes in the external environment. Despite the diversity, an emerging shift in orientation was identified that captures both the potential and challenges of future CRM. This fundamental change in perspective is next described in the form of the two evolutionary phases of CRM.

\section{From empowering firms}

CRM with a separate identity evolved in the early 1990s due to the data explosion of the 1980s. Vendors such as Siebel introduced commercial hardware and software solutions to better manage the overwhelming amounts of customer data confronting firms and to automate the sales process through contact management tools. After its introduction, CRM quickly developed into a rather firm-oriented construct. Commercial hardware and software solutions, such as sales force automation (SFA) and customer service and support (Kumar and Reinartz, 2006) were introduced to assist firms to better manage the sales force and customer service and support functions. Although there was a common interest in clarifying the misconception that CRM merely offered technological and software solutions to the rising number of challenges related to 
Accepted for publication in the Journal of Systems \& Information Technology

the management of customer data (Verhoef and Langerak, 2002), CRM was still centred on using customer data for managing customer relationships for the benefit of the firm. In the mid1990s the rise of analytical CRM allowed firms to analyse large quantities of customer data and identify relevant behavioural data and relationship development stages (Peacock, 1998). It was argued that there was a natural fit between data mining and CRM (Shankar and Winer, 2006; see also Homburg et al., 2009). This was true especially in contexts where the amount of data from a single customer was substantial and provided opportunities to identify different customer segments such as those with the most potential growth and most profitable customers and also to identify emerging customer trends.

Originally, both practitioners' and scholars' interest in CRM was driven by the paradigmatic change from transaction-based marketing to the management of customer relationships. In the early-2000s customer centricity, although having a slightly different meaning than the concept has today, was considered the basic building block of CRM (Bose, 2002; see also Bolton, 2004). At the core of customer-centric orientation was the interest in using CRM software to develop and establish long-term relationships with customers aimed at improving customer service and satisfaction (Stefanou et al., 2003; see also Rigby and Ledingham, 2004). During this phase, there seemed to be a common understanding that information technology would help the management of customer relationships (Dewhurst et al., 1999; Karimi et al., 2001; see also Campbell, 2003). However, gradually the research into CRM evolved under multiple banners resulting in a fragmented set of approaches, definitions, and research results. Firm centricity took over from customer centricity - research centred on firms' CRM activities such as segmentation, identification of the most profitable customers, and cross-selling (see e.g. Ryals, 2005). Firms 
Accepted for publication in the Journal of Systems \& Information Technology

used customer data instrumentally to serve their own purposes. Customer data was the firm's asset, forfeiting customer centricity and leaving it unguarded.

More recently, the strategic nature of CRM has been emphasized over the view that CRM is a process, philosophy, capability or technology (Zablah et al., 2005). Strategic CRM is about treating each customer differently, and consequently, maximizing the lifetime value of each customer to the organization (Peppard, 2000; Reichheld, 1996). According to Peppers and Rogers (2011, p. 7) in today's business environment 'all businesses will be embracing customer strategies sooner or later, with varying degrees of enthusiasm and success'. This is mainly due to two factors: customers want to be treated individually and as a strategy it is a more efficient way of doing business. In practice, strategic CRM includes different ways of 'improving shareholder value through the development of appropriate relationships with key customers and customer segments' (Payne and Frow, 2005, p. 268; see also Payne and Frow, 2004). These include the generation of customer data, identifying the most valuable customers over time, enhancing customer loyalty by interacting with the customers, and providing customized services and products, all the while reducing costs (Rigby et al., 2002; Cao and Gruca, 2005). This basic idea of strategic CRM has also been referred to as the IDIC-model (identifying, differentiating, interacting, and customizing) (Peppers and Rogers, 2004; 2011), emphasizing the importance to a successful CRM strategy of selecting the right customers at the very beginning.

The lack of a common definition of CRM and the pluralistic nature of the concept have resulted in the research field becoming fragmented and inconsistent. For example, Reinartz et al. (2004) show that the implementation of CRM processes has the strongest effect on relationship maintenance followed by relationship initiation. However, they also argue that CRM technology might even have a negative effect on performance (see also Jayachandran et al., 2005). A recent 
Accepted for publication in the Journal of Systems \& Information Technology

study confirms this view by showing that CRM does not affect firm performance directly as the link is mediated by cost leadership and differentiation (Reimann et al., 2010).

\section{Towards empowering customers}

Recent research, with few exceptions (e.g., Ernst et al., 2011), has not succeeded in reclaiming customer centricity as the fundamental determinant of the CRM framework despite the increasing number of CRM articles emphasizing the strategic nature of CRM. The current CRM framework has not managed to address the customer perspective adequately, and consequently customers may feel that they receive no benefits from "giving" their data for the use of a firm: the dark side of CRM may become reality (Boulding et al., 2005, p. 159; Frow et al., 2011; for a practical illustration, see Humby et al., 2003, pp. 160-161).

Private and public initiatives are increasingly reclaiming ownership of customer data on behalf of the customers. Service applications are developed that refine customer data for the benefit of the customer. For example, Nutrition Code by the Finnish retailer, Kesko Corporation, combines point-of-sale data with the nutritional information of the groceries and gives this information back to customers. As a result, customers are provided with information about the nutritional value of their groceries. In the same vein, the recent MyData initiative by the UK government, in which major businesses provide customers with an opportunity to reclaim their data for their own use, offers yet another sign of the emerging change in thinking in terms of customer data utilization. The MyData initiative attempts to put consumers in charge in a way that they are better able to get the best deals from retailers and pays special attention to the most vulnerable consumers who may not otherwise benefit from the rapidly changing technological and social environment. The British government's recent publication “Better Choices: Better 
Accepted for publication in the Journal of Systems \& Information Technology

Deals. Consumers Powering Growth" opens up the MyData initiative and finds three main drivers of the changing business environment (BIS, 2011). First, the growth of new technologies such as the internet and increasing use of mobile phones and applications have opened up new channels for consumers to find, compare and buy goods and services. Second, the increasing use of data coming from customers' purchasing histories has allowed firms to understand their customers' purchasing behaviour, facilitating personalized recommendations based on transaction history. Third, consumers are now collaborating across the economy for example by sharing products such as cars or bicycles or collectively giving feedback and offering new product development ideas. Current CRM research does not address these new forms of customer data usage, which confirms the need to reconfigure the role of customer data within the CRM framework.

As a reaction to the forfeiting of customer centricity, some have recently characterized the CRM framework (as well as the general marketing framework) as a power shift from marketers to customers (e.g. Hennig-Thurau et al., 2010). The private and public initiatives reclaiming ownership of customer data for the customers illuminates this view, as does a more holistic cross-functional view of CRM and its role in managing customer relationships to co-create value (Lambert, 2010).

A specific and important aspect of co-creation is the framework of social CRM (formerly called CRM 2.0), which refers to the transformation of communications technologies. This follows the advent of social media, which has changed how companies interact with their customers and prospects, and how customers interact with each other (Greenberg, 2010a). This dates back to 1996 when Stone, Woodcock, and Wilson (1996) proposed that future customers would increasingly manage their firm relationships themselves with the help of new technologies 
Accepted for publication in the Journal of Systems \& Information Technology

and that 'companies need to prepare themselves for this world' ( $\mathrm{p}$. 675). In this new world, customers would increasingly use new digital communications channels to manage their relationships with firms (see Zheng, 2011). Social CRM highlights the importance of optimizing customer experience by placing greater emphasis on the growing number of customer touch points with the company.

The purpose of the new communications channels such as blogs, discussion forums, and social networks in the new CRM framework is simply to engage customers in a regular dialogue. Greenberg (2010b, p. 139) states that the role of the new communication channels is 'to provide communication pipelines with your customers so you can have a conversation with them regularly'. Consequently, value co-creation becomes an increasingly important element of CRM strategies (Maklan et al., 2008; Nambisan and Baron, 2007). Against this backdrop, customers increasingly take part in the company's various processes such as new product development. In a recent study, Ernst et al. (2011) argue that firms should link CRM to new product development as 'CRM puts the customer into the central focus of multiple organizational activities' and 'therefore, CRM could be employed to systematically leverage customer-related information to better align NPD with market requirements' (p. 291). According to Hennig-Thurau et al. (2010), the new communications channels offer organizations novel ways to reach customers, communicate with them, and measure their activity. They state that this is of special value to marketing in general and CRM in particular.

\section{IMPLICATIONS FOR CRM RESEARCH}

The CRM framework in its current form is a heavily firm-oriented construct and focuses mainly on supporting firms' value-creating processes instead of identifying ways to harness the potential 
Accepted for publication in the Journal of Systems \& Information Technology

of customer data for the benefit of the customers. When we factor in the increasing concern over companies' misuse of customer data and other immoral CRM-related behaviour such as financial exploitation, customer lock-in, and invasion of privacy one can conclude that the shift toward “enlightened" CRM strategies (Frow et al., 2011) is a natural consequence of the inadequacy of the current CRM framework to serve customer needs.

However, the view of customer data as being solely owned by the firm is being questioned as the private and public sectors launch various service applications and initiatives intended to support customers' value creation through the utilization of customer data. Customer data is not used only internally in support of the company's value creation but also externally for the benefit of the customer. Customer data is used not only as a firm resource, but also as a resource for customer value creation. This opens up a wide variety of business opportunities that go beyond the traditional exchange. In addition to goods, firms can provide customers with information that can support customers' value creation. This shift in attention also has major implications for the further development of the CRM framework.

\section{<Take in Figure 1 approximately here>}

Consequently, and as illustrated in Figure 1, future research should concentrate on identifying CRM activities that capture the potential of customer data that both empowers firms and can be used for the benefit of the customer too. This necessitates understanding customer value creation as a resource integration process, where in addition to goods or services, other resources, such as information resulting from reverse use of customer data, are needed to actualize the value (see Grönroos, 2008; Grönroos and Helle, 2010). Consequently, developing data mining techniques 
Accepted for publication in the Journal of Systems \& Information Technology

and skills that help firms to refine customer data into information that can be used as an input resource for customer value-creating processes is of the greatest importance to future CRM endeavours.

According to Greenberg (cited in Peppers and Rogers, 2011, p. 461) the new media environment has empowered customers and created a new segment called 'social customers'. This group trusts their peer group more than anyone else and wants to actively use companies and brands as problem solvers according to the requirements of their personal agendas. This leads to a new situation in which organizations have to rethink how they interact with this new social customer segment. Good examples of companies that have attempted to become social organizations and are thus tuning their communications model to become a real dialogue are those that offer company-supported forums and communities such as Dell, Ford USA, Salesforce.com, Starbucks, Samsung and Nokia, to mention just a few. These firms have used the web for co-creation purposes and are constantly asking their community members how their products and services could be improved further.

\section{DISCUSSION AND CONCLUSIONS}

$\mathrm{CRM}$ is under pressure to adapt to changing market environments such as the increasing service orientation of firms, value co-creation and social media. Given these fundamental changes, the purpose of this paper was to explore and analyse the contemporary CRM framework and identify future research directions. To achieve this, a thorough literature review was conducted. It can be argued conclusively that as a management approach, CRM is gradually shifting attention toward customers and identifying ways of harnessing the potential of CRM for the benefit of the customer. Moving the locus of CRM from empowering firms to empowering customers, from 
Accepted for publication in the Journal of Systems \& Information Technology

internal to external and from using it as a vehicle for firm value creation to become a vehicle for customer value creation offers the key to serving customers rather than selling goods. It readjusts CRM to better meet the paradigmatic change from a goods orientation to a service orientation. This holds major managerial implications too. Firms should extend their view to customer data usage toward using customer data for the benefit of the customer. Hence, future CRM activities could be directed to better serving customers instead of the limited focus on internal customer data usage within the firm. This opens up both new opportunities for service development and building of competitive advantages.

The extended role of CRM does not diminish the importance of customer data in a firm's current CRM practices. Customer data is still, and will continue to be, a critically important input resource supporting a firm's processes. However, also using customer data for the benefit of the customer, to serve customers better, is clearly an emerging phenomenon. Extending the CRM framework to address the customer benefits of customer data utilization can offer unique opportunities for firms designing and implementing their customer relationship strategies. CRM must adapt to a business environment where new forms of exchange are emerging and where traditional customer and firm roles quickly become outdated and are recreated. Firms operating within banking, telecommunications, retailing, hospitality, travel, and health care industries, to name but a few, possess large amounts of valuable customer data that, when combined with a holistic understanding of the resources needed in customer value-creating processes and practices, can provide a unique competitive advantage. These industries set the pace for revitalizing $\mathrm{CRM}$ in practice. Consequently, firms can establish a true win-win customer relationship that discards the conventional CRM-philosophy of "market to" and embraces "market with" (Lusch, 2007). Furthermore, refining and giving customer data back to customers 
Accepted for publication in the Journal of Systems \& Information Technology

may represent a future mechanism through which companies deepen their customer relationship management and develop it to a whole new level. This change in perspective opens up a whole new spectrum of ways in which companies can better engage with their customers' everyday lives, one of the most fundamental objectives of contemporary marketing management. 
Accepted for publication in the Journal of Systems \& Information Technology

\section{REFERENCES}

BIS (Department for Business Innovation and Choice) (2011), "Better Choices:

Better Deals. Consumers Powering Growth", available at:

http://www.bis.gov.uk/assets/biscore/consumer-issues/docs/b/11-749-better-choices-betterdeals-consumers-powering-growth.pdf (accessed 25 May 2012).

Bohling, T., Bowman, D., LaValle, S., Mittal, V., Narayandas, D., Ramani, G. and Varadarajan, R. (2006), "CRM implementation: Effectiveness issues and insights", Journal of Service Research, Vol. 9 No. 2, pp. 184-194.

Bolton, M. (2004), "Customer centric business processing", International Journal of Productivity and Performance Management, Vol. 53 Nos. 1/2, pp. 44-51.

Bose, R. (2002), “Customer relationship management: Key components for IT success”, Industrial Management \& Data Systems, Vol. 102 No. 2, pp. 89-97.

Boulding, W., Staelin, R., Ehret, M. and Johnston, W.J. (2005), “A customer relationship management roadmap: What is known, potential pitfalls, and where to go", Journal of Marketing, Vol. 69 No. 4, pp. 155-166.

Cao, Y. and Gruca, T.S. (2005), "Reducing adverse selection through customer relationship management”, Journal of Marketing, Vol. 69 No. 4, pp. 219-229.

Campbell, A.J. (2003), “Creating customer knowledge competence: Managing customer relationship management programs strategically", Industrial Marketing Management, Vol. 32 No. 5, pp. 375-383.

Chalmeta, R. (2006), "Methodology for customer relationship management", Journal of Systems and Software, Vol. 79 No. 7, pp. 1015-1024. 
Accepted for publication in the Journal of Systems \& Information Technology

Chang, H.H. (2007), "Critical factors and benefits in the implementation of customer relationship management”, Total Quality Management \& Business Excellence, Vol. 18 No. 5, pp. 483508.

Chen, I.J. and Popovich, K. (2003), “Understanding customer relationship management (CRM). People, process and technology”, Business Process Management Journal, Vol. 9 No. 5, pp. $672-688$.

Coltman, T. (2007), "Why build a customer relationship management capability?" Journal of Strategic Information Systems, Vol. 16 No. 3, pp. 301-320.

Cooper, M.J., Gwin, C.F. and Wakefield, K.L. (2008), “Cross-functional interface and disruption in CRM projects: Is marketing from Venus and information systems from Mars?" Journal of Business Research, Vol. 61 No. 4, pp. 292-299.

Dewhurst, F., Martinez Lorente, A.R., Dale, B.G. (1999), "Total quality management and information technologies: an exploration of the issues", International Journal of Quality \& Reliability Management, Vol. 16 No.4, pp. 392-406.

du Plessis, M. and Boon, J.A. (2004), "Knowledge management in eBusiness and customer relationship management: South African case study findings", International Journal of Information Management, Vol. 24 No. 1, pp. 73-86.

Ehret, M. (2004), "Managing the trade-off between relationships and value networks. Towards a value-based approach of customer relationship management in business-to-business markets", Industrial Marketing Management, Vol. 33 No. 6, pp. 465-473.

Ernst, H., Hoyer, W.D. and Krafft, M. (2011), “Customer relationship management and company performance-the mediating role of new product performance", Journal of the Academy of Marketing Science, Vol. 39 No. 2, pp. 290-306. 
Accepted for publication in the Journal of Systems \& Information Technology

Fan, Y.-W. and Ku, E. (2010), "Customer focus, service process fit and customer relationship management profitability: The effect of knowledge sharing", The Service Industries Journal, Vol. 30 No. 2, pp. 203-223.

Frow, P., Payne, A., Wilkinson, I.F. and Young, L. (2011), “Customer management and CRM: Addressing the dark side", Journal of Services Marketing, Vol. 25 No. 2, pp. 79-89.

Greenberg, P. (2010a), “The impact of CRM 2.0 on customer insight", Journal of Business \& Industrial Marketing, Vol. 25 No. 6, pp. 410-419.

Greenberg, P. (2010b), CRM at the Speed of Light, Fourth Edition: Social CRM Strategies, Tools, and Techniques for Engaging Your Customers, McGraw-Hill, New York.

Grönroos, C. (2008), "Service logic revisited: Who creates value? And who co-creates?" European Business Review, Vol. 20 No. 4, pp. 298-314.

Grönroos, C. and Helle, P. (2010), “Adopting a service logic in manufacturing: Conceptual foundation and metrics for mutual value creation”, Journal of Service Management, Vol. 21 No. 5, pp. 564-590.

Hennig-Thurau, T., Malthouse, E.C., Friege, C., Gensler, S., Lobschat, L., Rangaswamy, A. and Skiera, B. (2010), “The impact of new media in consumer relationships", Journal of Service Research, Vol. 13 No. 3, pp. 311-330.

Homburg, C., Steiner, V.V. and Totzek, D. (2009), "Managing dynamics in a customer portfolio”, Journal of Marketing, Vol. 73 No. 5, pp. 70-89.

Humby, C., Hunt, T. and Phillips, T. (2003). Scoring points. How Tesco is winning customer loyalty, Kogan Page, London. 
Accepted for publication in the Journal of Systems \& Information Technology

Jayachandran, S., Sharma, S., Kaufman, P. and Raman, P. (2005), "The role of relational information processes and technology use in customer relationship management", Journal of Marketing, Vol. 69 No. 4, pp. 177-192.

Kamakura W., Mela, C.F., Ansari A., Bodapati, A., Fader, P., Iyengar, R., Naik, P., Neslin, S., Sun, B., Verhoef, P.C., Wedel, M. and Wilcox, R. (2005), "Choice models and customer relationship management", Marketing Letters, Vol. 16 Nos. 3/4, pp. 279-291.

Karimi, R., Somers, T.M. and Gupta, Y.P. (2001), "Impact of information technology management practices on customer service", Journal of Management Information Systems, Vol. 17 No.4, pp. 125-158.

Kim, H.-S. and Kim, Y.-G. (2009), “A CRM performance measurement framework: Its development process and application”, Industrial Marketing Management, Vol. 38 No. 4, pp. 477-489.

King, S.F. and Burgess, T.F. (2008), “Understanding success and failure in customer relationship management”, Industrial Marketing Management, Vol. 37 No. 4, pp. 421-431.

Ko, E., Kim, S.H., Kim, M. and Woo, J.Y. (2008), "Organizational characteristics and the CRM adoption process", Journal of Business Research, Vol. 61 No. 1, pp. 65-74.

Kotorov, R. (2003), “Customer relationship management: Strategic lessons and future directions”, Business Process Management Journal, Vol. 9 No. 5, pp. 566-571.

Krasnikov, A., Jayachandran, S. and Kumar, V. (2009), “The impact of customer relationship management implementation on cost and profit efficiencies: Evidence from the US commercial banking industry", Journal of Marketing, Vol. 73 No. 6, pp. 61-76.

Kumar, V. and Reinartz, W.J. (2006), Customer relationship management. A databased approach, John Wiley \& Sons, Hoboken. 
Accepted for publication in the Journal of Systems \& Information Technology

LaPlaca, P.J. (2004),’Letter from the editor. Special issue on customer relationship marketing”, Industrial Marketing Management, Vol. 33 No. 6, pp. 463-464

Lambert, D.M. (2010), “Customer relationship management as a business process", Journal of Business \& Industrial Marketing, Vol. 25 Nos. 1-2, pp. 4-17.

Li, L.-Y. (2011), "Marketing metrics' usage: Its predictors and implications for customer relationship management”, Industrial Marketing Management, Vol. 40 No. 1, pp. 139-148.

Li, C., Xu, Y. and Li, H. (2005), “An empirical study of dynamic customer relationship management”, Journal of Retailing and Consumer Services, Vol. 12 No. 6, pp. 431-441.

Lin Y., Su, H.Y. and Chien, S.A. (2006), "Knowledge-enabled procedure for customer relationship management”, Industrial Marketing Management, Vol. 35 No. 4, pp. 446-456.

Lindgreen, A. and Antioco, M. (2005), "Customer relationship management: The case of a European bank", Marketing Intelligence \& Planning, Vol. 23 Nos. 2/3, pp. 136-154.

Lusch, R.F. (2007), “Marketing's evolving identity: Defining our future”, Journal of Public Policy \& Marketing, Vol. 26 No 2, pp. 261-268.

Maglio, P.P. and Spohrer, J. (2008), "Fundamentals of service science”, Journal of the Academy of Marketing Science, Vol. 36 No. 1, pp. 18-20.

Maklan, S., Knox, S. and Ryals, L. (2008), "New trends in innovation and customer relationship management - a challenge for market researchers", International Journal of Market Research, Vol. 50 No. 2, pp. 221-240.

Mendoza, L.E., Marius, A., Perez, M. and Griman, A.C. (2007), "Critical success factors for a customer relationship management strategy", Information and Software Technology, Vol. 49 No. 8, pp. 913-945. 
Accepted for publication in the Journal of Systems \& Information Technology

Mithas, S., Krishnan, M.S. and Fornell, C. (2005), "Why do customer relationship management applications affect customer satisfaction?” Journal of Marketing, Vol. 69 No. 4, pp. 201-209.

Nambisan, S. and Baron, R.A. (2007), "Interactions in virtual customer environments: Implications for product support and customer relationship management", Journal of Interactive Marketing, Vol. 21 No. 2, pp. 42-62.

Ngai, E.W.T. (2005), “Customer relationship management research (1992-2002). An academic literature review and classification”, Marketing Intelligence \& Planning, Vol. 23 No. 6, pp. $582-605$.

Parvatiyar, A. and Sheth, J.N. (2001), “Customer relationship management: Emerging practice, process, and discipline" Journal of Economic \& Social Research, Vol. 3 No. 2, pp. 1-34.

Payne, A. and Frow, P. (2004), "The role of multichannel integration in customer relationship management”, Industrial Marketing Management, Vol. 33 No. 6, pp. 527-538.

Payne, A. and Frow, P. (2005), “A strategic framework for customer relationship management”, Journal of Marketing, Vol. 69 No. 4, pp. 167-176.

Peacock, P.R. (1998), “Data Mining in Marketing: Part 1", Marketing Management, Vol. 6 No. 4, pp. 9-18.

Peppard, J. (2000), “Customer relationship management (CRM) in financial services”, European Management Journal, Vol. 18 No. 3, pp. 312-327.

Peppers, D. and Rogers, M. (2004), Managing customer relationships. A Strategic framework. John Wiley \& Sons, Hoboken.

Peppers, D. and Rogers, M. (2011), Managing customer relationships. A Strategic framework $\left(2^{\text {nd }} e d.\right)$, John Wiley \& Sons, Hoboken. 
Accepted for publication in the Journal of Systems \& Information Technology

Ramaseshan B., Bejou, D., Jain, S., Mason, C. and Pancras, J. (2006), "Issues and perspectives in global customer relationship management", Journal of Service Research, Vol. 9 No. 2, pp. 195-207.

Reichheld, F. (1996), The loyalty effect: The hidden force behind growth, profits and lasting value, Harvard Business School Press, Boston.

Reimann, M., Schilke, O. and Thomas, J.S. (2010), ”Customer relationship management and firm performance: The mediating role of business strategy", Journal of the Academy of Marketing Science, Vol. 38 No. 3, pp. 326-346.

Reinartz, W., Krafft, M. and Hoyer, W.D. (2004), "The customer relationship management process: Its measurement and impact on performance”, Journal of Marketing Research, Vol. 41 No. 3, pp. 293-305.

Richard, J.E., Thirkell, P.C. and Huff, S.L. (2007), “An examination of customer relationship management (CRM) technology adoption and its impact on business-to-business customer relationships", Total Quality Management \& Business Excellence, Vol. 18 No. 8, pp. 927945.

Richards, K.A. and Jones, E. (2008), “Customer relationship management: Finding value drivers", Industrial Marketing Management, Vol. 37 No. 2, pp. 120-130.

Rigby, D. K., Reichheld, F. and Schefter, P. (2002), “Avoid the four perils of CRM”, Harvard Business Review, Vol. 80 No. 2, pp. 101-109.

Rigby, D. K. and Ledingham, D. (2004), “CRM done right”, Harvard Business Review, Vol. 82 No. 11, pp. 118-129. 
Accepted for publication in the Journal of Systems \& Information Technology

Roberts, M.L., Liu, R.R. and Hazard, K. (2005), "Strategy, technology and organizational alignment: Key components of CRM success", Journal of Database Marketing \& Customer Strategy Management, Vol. 12 No. 4, pp. 315-326.

Roh T.H., Ahn, C.K. and Han, I. (2005), "The priority factor model for customer relationship management system success", Expert Systems with Applications, Vol. 28 No. 4, pp. 641-654.

Ryals, L. (2005), "Making customer relationship management work: The measurement and profitable management of customer relationships”, Journal of Marketing, Vol. 69 No. 4, pp. 252-261.

Shankar, V. and Winer, R.S. (2006), "When customer relationship management meets data mining”, Journal of Interactive Marketing, Vol. 20 Nos. 3/4, pp. 2-4.

Srinivasan, R. and Moorman, C. (2005), "Strategic firm commitments and rewards for customer relationship management in online retailing”, Journal of Marketing, Vol. 69 No. 4, pp. 193200.

Stefanou, C.J., Sarmaniotis, C. and Stafyla, A. (2003), "CRM and customer-centric knowledge management: An empirical research", Business Process Management Journal, Vol. 9 No. 5, pp. 617- 634 .

Stone M., Woodcock, N. and Wilson, M. (1996), "Managing the change from marketing planning to customer relationship management", Long Range Planning, Vol. 29 No. 5, pp. $675-683$.

Teo, T.S.H., Devadoss, P. and Pan, S.L. (2006), "Towards a holistic perspective of customer relationship management (CRM) implementation: A case study of the Housing and Development Board, Singapore”, Decision Support Systems, Vol. 42 No. 3, pp. 1613-1627. 
Accepted for publication in the Journal of Systems \& Information Technology

The New York Times, "Show us the data. (It's ours, after all)", available at: http://www.nytimes.com/2011/04/24/business/24view.html?_r=1 (accessed 23 May 2011).

Torkzadeh, G., Chang, J.C.-J. and Hansen, G.W. (2006), "Identifying issues in customer relationship management at Merck-Medco", Decision Support Systems, Vol. 42 No. 2, pp. 1116-1130.

Venkatesan, R., Kumar, V. and Bohling, T. (2007), “Optimal customer relationship management using Bayesian decision theory: An application for customer selection", Journal of Marketing Research, Vol. 44 No. 4, pp. 579-594.

Vargo, S.L. and Lusch, R.F. (2004), “Evolving to a new dominant logic for marketing”, Journal of Marketing, Vol. 68 No. 1, pp. 1-17.

Vargo, S.L. and Lusch, R.F. (2008), "Service-dominant logic: Continuing the evolution", Journal of the Academy of Marketing Science, Vol. 36 No. 2, pp. 1-10.

Vargo, S.L., Maglio, P.P. and Akaka, M.A. (2008), “On value and value co-creation: A service systems and service logic perspective", European Management Journal, Vol. 26 No. 3, pp. $145-152$.

Verhoef, P.C. (2003), “Understanding the effect of customer relationship management efforts on customer retention and customer share development", Journal of Marketing, Vol. 67 No. 4, pp. 30-45.

Verhoef, P.C. and Langerak, F. (2002), “Eleven misconceptions about customer relationship management“, Business Strategy Review, Vol. 13 No. 4. pp. 70-76.

Wilson, H., Clark, M. and Smith, B. (2007), "Justifying CRM projects in a business-to-business context: The potential of the benefits dependency network", Industrial Marketing Management, Vol. 36 No. 6, pp. 770-783. 
Accepted for publication in the Journal of Systems \& Information Technology

Xu, Y.R., Yen, D.C., Lin, B.S. and Chou, D.C. (2002), “Adopting customer relationship management technology”, Industrial Management \& Data Systems, Vol. 102 Nos. 8/9, pp. $442-452$.

Zablah, A.R., Bellenger, D.N. and Johnston, W.J. (2005), “An evaluation of divergent perspectives on customer relationship management: Towards a common understanding of an emerging phenomenon", Industrial Marketing Management, Vol. 33 No. 6, pp. 475-489.

Zheng, V. (2011), “The value propositions of adopting mCRM strategy in UK SMEs”, Journal of Systems and Information Technology, Vol. 13 No. 2, pp. 223-245. 


\section{LIST OF TABLES}

Table 1. Summary of the literature review

\begin{tabular}{|c|c|c|c|c|c|}
\hline No & Year & Author & Title & Journal & Method* \\
\hline 1. & 2011 & Ernst, Hoyer,\& Krafft & $\begin{array}{l}\text { Customer relationship management and company performance- }- \text { The } \\
\text { mediating role of new product performance }\end{array}$ & $\begin{array}{l}\text { Journal of the Academy of Marketing } \\
\text { Science }\end{array}$ & $\mathrm{E}$ \\
\hline 2. & 2011 & $\mathrm{Li}$ & $\begin{array}{l}\text { Marketing metrics' usage: Its predictors and implications for customer } \\
\text { relationship management }\end{array}$ & Industrial Marketing Management & $\mathrm{E}$ \\
\hline 3. & 2010 & $\mathrm{Fan} \& \mathrm{Ku}$ & $\begin{array}{l}\text { Customer focus, service process fit and customer relationship management } \\
\text { profitability: The effect of knowledge sharing }\end{array}$ & Services Industry Journal & $\mathrm{E}$ \\
\hline 4. & 2010 & Greenberg & The impact of CRM 2.0 on customer insight & $\begin{array}{l}\text { Journal of Business \& Industrial } \\
\text { Marketing }\end{array}$ & $\mathrm{C}$ \\
\hline 5. & 2010 & Lambert & Customer relationship management as a business process & $\begin{array}{l}\text { Journal of Business \& Industrial } \\
\text { Marketing }\end{array}$ & $\mathrm{E}$ \\
\hline 6. & 2010 & $\begin{array}{l}\text { Reimann, Schilke, \& } \\
\text { Thomas }\end{array}$ & $\begin{array}{l}\text { Customer relationship management and firm performance: The mediating } \\
\text { role of business strategy }\end{array}$ & $\begin{array}{l}\text { Journal of the Academy of Marketing } \\
\text { Science }\end{array}$ & $\mathrm{E}$ \\
\hline 7. & 2009 & Kim \& Kim & $\begin{array}{l}\text { A CRM performance measurement framework: Its development process and } \\
\text { application }\end{array}$ & Industrial Marketing Management & $\mathrm{E}$ \\
\hline 8. & 2009 & $\begin{array}{l}\text { Krasnikov, Jayachandran, } \\
\text { \& Kumar }\end{array}$ & $\begin{array}{l}\text { The impact of customer relationship management implementation on cost and } \\
\text { profit efficiencies: Evidence from the US commercial banking industry }\end{array}$ & Journal of Marketing & $\mathrm{E}$ \\
\hline 9. & 2008 & $\begin{array}{l}\text { Cooper, Gwin, \& } \\
\text { Wakefield }\end{array}$ & $\begin{array}{l}\text { Cross-functional interface and disruption in CRM projects: Is marketing } \\
\text { from Venus and information systems from Mars?" }\end{array}$ & Journal of Business Research & $\mathrm{E}$ \\
\hline 10. & 2008 & King \& Burgess & Understanding success and failure in customer relationship management & Industrial Marketing Management & $\mathrm{E}$ \\
\hline 11. & 2008 & Ko, Kim, Kim, \& Woo & Organisational characteristics and the CRM adoption process & Journal of Business Research & $\mathrm{C}$ \\
\hline 12. & 2008 & Maklan, Know, \& Ryals & $\begin{array}{l}\text { New trends in innovation and customer relationship management-A } \\
\text { challenge for market researchers }\end{array}$ & $\begin{array}{l}\text { International Journal of Market } \\
\text { Research }\end{array}$ & $\mathrm{E}$ \\
\hline 13. & 2008 & Richards \& Jones & Customer relationship management: Finding value drivers & Industrial Marketing Management & $\mathrm{C}$ \\
\hline 14. & 2007 & Chang & $\begin{array}{l}\text { Critical factors and benefits in the implementation of customer relationship } \\
\text { management }\end{array}$ & $\begin{array}{l}\text { Total Quality Management \& } \\
\text { Business Excellence }\end{array}$ & $\mathrm{E}$ \\
\hline 15. & 2007 & Coltman & Why build a customer relationship management capability? & $\begin{array}{l}\text { Journal of Strategic Information } \\
\text { Systems }\end{array}$ & $\mathrm{E}$ \\
\hline 16. & 2007 & $\begin{array}{l}\text { Mendoza, Marius, Perez, } \\
\text { \& Griman }\end{array}$ & Critical success factors for a customer relationship management strategy & $\begin{array}{l}\text { Information and Software } \\
\text { Technology }\end{array}$ & $\mathrm{E}$ \\
\hline
\end{tabular}




\begin{tabular}{|c|c|c|c|c|c|}
\hline 17. & 2007 & Nambisan \& Baron & $\begin{array}{l}\text { Interactions in virtual customer environments: Implications for product } \\
\text { support and customer relationship management }\end{array}$ & Journal of Interactive Marketing & $\mathrm{E}$ \\
\hline 18. & 2007 & Richard, Thirkell, \& Huff & $\begin{array}{l}\text { An examination of customer relationship management (CRM) technology } \\
\text { adoption and its impact on business-to-business customer relationships }\end{array}$ & $\begin{array}{l}\text { Total Quality Management \& } \\
\text { Business Excellence }\end{array}$ & $\mathrm{E}$ \\
\hline 19. & 2007 & $\begin{array}{l}\text { Venkatesan, Kumar, \& } \\
\text { Bohling }\end{array}$ & $\begin{array}{l}\text { Optimal customer relationship management using Bayesian decision theory: } \\
\text { An application for customer selection }\end{array}$ & Journal of Marketing Research & $\mathrm{E}$ \\
\hline 20. & 2007 & Wilson, Clark, \& Smith & $\begin{array}{l}\text { Justifying CRM projects in a business-to-business context: The potential of } \\
\text { the Benefits Dependency Network }\end{array}$ & Industrial Marketing Management & $\mathrm{E}$ \\
\hline 21. & 2006 & $\begin{array}{l}\text { Bohling, Bowman, } \\
\text { LaValle, Mittal, } \\
\text { Narayandas, Ramani, \& } \\
\text { Varadarajan }\end{array}$ & CRM implementation: Effectiveness issues and insights & Journal of Service Research & $\mathrm{E}$ \\
\hline 22. & 2006 & Chalmeta & Methodology for customer relationship management & Journal of Systems and Software & $\mathrm{C}$ \\
\hline 23. & 2006 & Lin, Su, \& Chien & Knowledge-enabled procedure for customer relationship management & Industrial Marketing Management & $\mathrm{E}$ \\
\hline 24. & 2006 & $\begin{array}{l}\text { Ramaseshan, Bejou, Jain, } \\
\text { Mason, \& Pancras }\end{array}$ & Issues and perspectives in global customer relationship management & Journal of Service Research & $\mathrm{C}$ \\
\hline 25. & 2006 & Teo, Devadoss, \& Pan & $\begin{array}{l}\text { Towards a holistic perspective of customer relationship management (CRM) } \\
\text { implementation: A case study of the Housing and Development Board, } \\
\text { Singapore }\end{array}$ & Decision support Systems & $\mathrm{E}$ \\
\hline 26. & 2006 & $\begin{array}{l}\text { Torkzadeh, Chang, \& } \\
\text { Hansen }\end{array}$ & Identifying issues in customer relationship management at Merck-Medco & Decision support Systems & $\mathrm{E}$ \\
\hline 27. & 2005 & $\begin{array}{l}\text { Boulding, Staelin, Ehret, } \\
\& \text { Johnston }\end{array}$ & $\begin{array}{l}\text { A customer relationship management roadmap: What is known, potential } \\
\text { pitfalls, and where to go }\end{array}$ & Journal of Marketing & $\mathrm{C}$ \\
\hline 28. & 2005 & Cao \& Gruca & Reducing adverse selection through customer relationship management & Journal of Marketing & $\mathrm{E}$ \\
\hline 29. & 2005 & $\begin{array}{l}\text { Jayachandran, Sharma, } \\
\text { Kaufman, \& Raman }\end{array}$ & $\begin{array}{l}\text { The role of relational information processes and technology use in customer } \\
\text { relationship management }\end{array}$ & Journal of Marketing & $\mathrm{E}$ \\
\hline 30. & 2005 & $\begin{array}{l}\text { Kamakura, Mela, Ansari, } \\
\text { Bodapati, Fader, Iyengar, } \\
\text { Naik, Neslin, Sun, } \\
\text { Verhoef, Wedel, \& } \\
\text { Wilcox }\end{array}$ & Choice models and customer relationship management & Marketing Letters & $\mathrm{C}$ \\
\hline 31. & 2005 & $\mathrm{Li}, \mathrm{Xu}, \& \mathrm{Li}$ & An empirical study of dynamic customer relationship management & $\begin{array}{l}\text { Journal of Retailing and Consumer } \\
\text { Services }\end{array}$ & $\mathrm{E}$ \\
\hline 32. & 2005 & Lindgreen \& Antioco & Customer relationship management: The case of a European bank & Marketing Intelligence \& Planning & $\mathrm{E}$ \\
\hline 33. & 2005 & $\begin{array}{l}\text { Mithas, Krishnan \& } \\
\text { Fornell }\end{array}$ & $\begin{array}{l}\text { Why do customer relationship management applications affect customer } \\
\text { satisfaction? }\end{array}$ & Journal of Marketing & $\mathrm{E}$ \\
\hline
\end{tabular}




\begin{tabular}{|c|c|c|c|c|c|}
\hline 34. & 2005 & Ngai & $\begin{array}{l}\text { Customer relationship management research (1992-2002). An academic } \\
\text { literature review and classification }\end{array}$ & Marketing Intelligence \& Planning & $\mathrm{C}$ \\
\hline 35. & 2005 & Payne \& Frow & A strategic framework for customer relationship management & Journal of Marketing & $\mathrm{E}$ \\
\hline 36. & 2005 & Roberts, Liu, \& Hazard & $\begin{array}{l}\text { Strategy, technology and organisational alignment: Key components of CRM } \\
\text { success }\end{array}$ & $\begin{array}{l}\text { Journal of Database Marketing \& } \\
\text { Customer Strategy Management }\end{array}$ & $\mathrm{C}$ \\
\hline 37. & 2005 & Roh, Ahn, \& Han & $\begin{array}{l}\text { The priority factor model for customer relationship management system } \\
\text { success }\end{array}$ & Expert Systems with Applications & $\mathrm{E}$ \\
\hline 38. & 2005 & Ryals & $\begin{array}{l}\text { Making customer relationship management work: The measurement and } \\
\text { profitable management of customer relationships }\end{array}$ & Journal of Marketing & $\mathrm{E}$ \\
\hline 39. & 2005 & Srinivasan \& Moorman & $\begin{array}{l}\text { Strategic firm commitments and rewards for customer relationship } \\
\text { management in online retailing }\end{array}$ & Journal of Marketing & $\mathrm{E}$ \\
\hline 40. & 2005 & $\begin{array}{l}\text { Zablah, Bellenger, \& } \\
\text { Johnston }\end{array}$ & $\begin{array}{l}\text { An evaluation of divergent perspectives on customer relationship } \\
\text { management: Towards a common understanding of an emerging } \\
\text { phenomenon }\end{array}$ & Industrial Marketing Management & $\mathrm{C}$ \\
\hline 41. & 2004 & Bolton & Customer-centric business processing & $\begin{array}{l}\text { International Journal of Productivity } \\
\text { and Performance Management }\end{array}$ & $\mathrm{C}$ \\
\hline 42. & 2004 & du Plessis \& Boon & $\begin{array}{l}\text { Knowledge management in eBusiness and customer relationship } \\
\text { management: South African case study findings }\end{array}$ & $\begin{array}{l}\text { International Journal of Information } \\
\text { Management }\end{array}$ & $\mathrm{E}$ \\
\hline 43. & 2004 & Ehret & $\begin{array}{l}\text { Managing the trade-off between relationships and value networks. Towards a } \\
\text { value-based approach of customer relationship management in business-to- } \\
\text { business markets }\end{array}$ & Industrial Marketing Management & $\mathrm{C}$ \\
\hline 44. & 2004 & Payne \& Frow & The role of multichannel integration in customer relationship management & Industrial Marketing Management & $\mathrm{C}$ \\
\hline 45. & 2004 & Reinartz, Krafft, \& Hoyer & $\begin{array}{l}\text { The customer relationship management process: Its measurement } \\
\text { and impact on performance }\end{array}$ & Journal of Marketing Research & $\mathrm{E}$ \\
\hline 46. & 2004 & Rigby \& Ledingham & CRM done right & Harvard Business Review & $\mathrm{C}$ \\
\hline 47. & 2003 & Campbell & $\begin{array}{l}\text { Creating customer knowledge competence: Managing customer relationship } \\
\text { management programs strategically }\end{array}$ & Industrial Marketing Management & $\mathrm{E}$ \\
\hline 48. & 2003 & Chen \& Popovich & $\begin{array}{l}\text { Understanding customer relationship management (CRM). People, process } \\
\text { and technology }\end{array}$ & $\begin{array}{l}\text { Business Process Management } \\
\text { Journal }\end{array}$ & $\mathrm{C}$ \\
\hline 49. & 2003 & Kotorov & Customer relationship management: Strategic lessons and future directions & $\begin{array}{l}\text { Business Process Management } \\
\text { Journal }\end{array}$ & $\mathrm{C}$ \\
\hline 50. & 2003 & Verhoef & $\begin{array}{l}\text { Understanding the effect of customer relationship management efforts on } \\
\text { customer retention and customer share development }\end{array}$ & Journal of Marketing & $\mathrm{E}$ \\
\hline
\end{tabular}

*Notes: E=Empirical; $\mathrm{C}=$ Conceptual 
Accepted for publication in the Journal of Systems \& Information Technology

\section{LIST OF FIGURES}

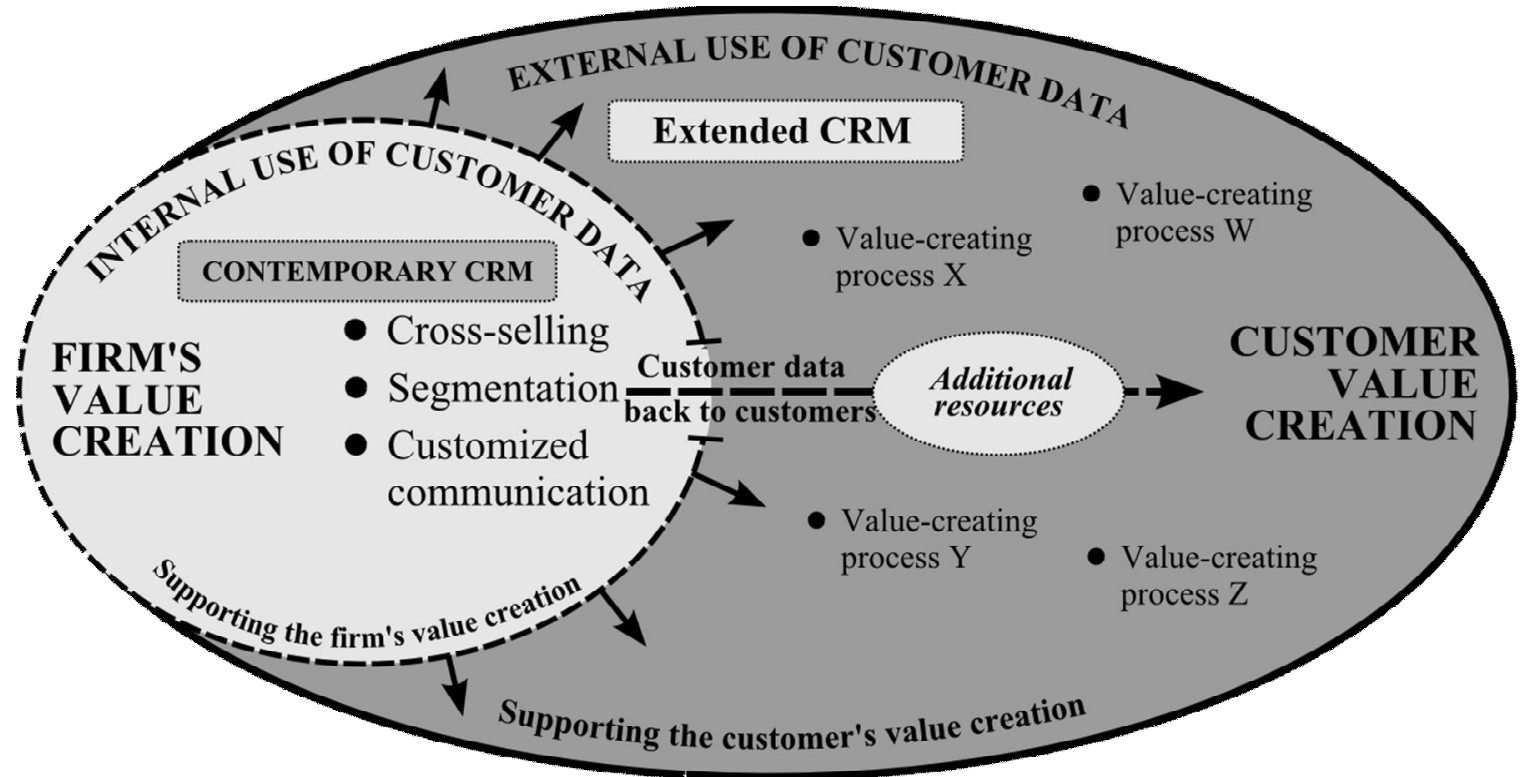

Figure 1. From internal to external use of customer data - extending the CRM framework. 